\title{
Is Earnings Quality Associated with Corporate Social Responsibility? Evidence from the Korean Market
}

\author{
Bohyun Yoon ${ }^{1}\left(\mathbb{D}\right.$, Byul Kim $^{2}$ and Jeong Hwan Lee ${ }^{2, * \mathbb{C}}$ \\ 1 Division of Economics and Information Statistics, Kangwon National University, Chuncheon 24341, Korea \\ 2 College of Economics and Finance, Hanyang University, Seoul 04763, Korea \\ * Correspondence: jeonglee@hanyang.ac.kr; Tel.: +82-222-201-036
}

Received: 5 July 2019; Accepted: 29 July 2019; Published: 30 July 2019

check for updates

\begin{abstract}
Socially responsible firms are believed to behave in a responsible manner to restrict earnings management and thus deliver more reliable and transparent financial information to investors. We test this hypothesis by predicting a higher quality of financial reporting for socially responsible firms in the Korean market. The entire sample analysis provides evidence for the hypothesis in the use of discretionary accruals as proxy variables for the quality of financial reporting. However, our sub-sample analysis indicates that such weak support is driven by a group of environmentally sensitive firms and the affiliates of large family-owned conglomerates, or chaebol. Socially responsible firms are less likely to be involved with earnings management in the group of non-environmentally sensitive industries and non-chaebol affiliates. These firms provide a better quality of financial reporting in terms of both the use of discretionary accruals and real activity manipulations. In line with recent studies, our findings suggest that ethical concerns in producing high-quality financial reports rely significantly on firm characteristics.
\end{abstract}

Keywords: chaebol; corporate social responsibility; earnings management; ESG score; environmentally sensitive industries; Korea

\section{Introduction}

Corporate social responsibility (CSR) can be defined as a corporation's management practices beyond the requirements of law. The employment of CSR strategies is closely related to a firm's sustainable growth path. In particular, customers, investors, and other stakeholders increasingly require transparency about all dimensions of a corporation, including the accuracy and transparency of financial reporting. In fact, recent studies [1-3] confirm that firms actively engaged in socially responsible activities have a better quality of financial reporting.

To be specific, extant studies on CSR [1,3] provide a theoretical background and empirical evidence of the better quality of financial reporting for socially responsible firms. A number of corporate theories provide theoretical frameworks that integrate business ethics with economic decisions $[4,5]$. Firms conducting business based on corporations and trust have incentives to commit to ethical behavior [4,5], which includes more transparent financial reporting [1-3]. This is because these firms can satisfy the ethical expectations of stakeholders in society by providing more reliable and transparent financial reporting.

This paper examines how a firm's engagement in socially responsible activities affects the quality of financial reporting in the Korean financial market in terms of earnings management practices. Publishing a high quality of reporting is important because it will positively affect investors and other stakeholders in making investment, financing, and other resource allocation decisions. This quality of financial reporting is analyzed in the literature from three major perspectives, namely earnings management, financial restatements, and timeliness, as well as their combined indices [6-8]. 
In particular, the degree of earnings management, which captures the quality of reported earnings in financial reporting, is one of representative ways to examine the quality of financial reporting in the literature [6].

We deliberately choose the sample of Korean firms to examine the relationship between CSR performances and the quality of financial reporting. First of all, extant studies mainly consider the effect of CSR practices in advanced markets such as the U.S. or the U.K financial markets [1,9]. A branch of studies tried to conduct international studies within limited sample of firms [3,10], mostly European companies [3]. The Korean market is now transitioning from an emerging market towards an advanced one, and it has a well-established measure to represent a corporation's CSR practices, unlike other developing countries. By choosing the Korean market, we fill in the gap of the extant literature largely focusing on advanced markets. Furthermore, the Korean market is interesting from the perspective of governance structure as well. The groups of family-owned large business corporations play dominant roles in the market and these firms are under more severe requirements with regard to their financing, disclosure, and governance policies.

For this purpose, we adopt various proxy variables for earnings management related to the use of discretionary accruals and real activities manipulations. Then we examine how these measures of earnings management are related to the degree of a corporation's socially responsible activity based on the environmental, social, and corporate governance (ESG) score published by the Korea Corporate Governance Service (KCGS). A sample of publicly traded Korean firms is investigated from 2010 to 2015, mostly those listed on the Korea Exchange. We adopt cross-sectional regression models to test the hypothesis.

Recent studies highlight that the effect of CSR activity on corporate polies is not equally applicable for firms with different characteristics. For instance, firms in environmentally sensitive industries show different valuation effects from CSR activities [11]. In particular, in the Korean market, CSR activities for the affiliates of large family-owned conglomerates, called chaebol, are shown to have different valuation effects [12]. By following these recent developments, we conduct sub-sample analysis between the groups of firms in environmentally sensitive industries and non-sensitive industries. The categorization of chaebol affiliates and non-chaebol affiliates are examined in our analysis as well.

The main findings of this work can be summarized as follows. Most of all, our entire sample analysis weakly supports the hypothesis predicting a higher quality of financial reporting for more socially responsible firms. Our analysis confirms that more socially responsible firms are less likely to manage earnings by using discretionary accruals. However, the analysis of real activity manipulation does not strongly support the hypothesis; a firm's active CSR engagements indicate limited real activity manipulation in terms of abnormal discretionary expenses, but no significant difference in the use of abnormal cash flow and abnormal production costs in the Korean market.

Our sub-sample analysis indicates that such a weak set of evidence is driven by the group of firms in environmentally sensitive industries, or chaebol affiliates. To be specific, more socially responsible firms in environmentally non-sensitive industries or non-chaebol affiliates have a better quality of financial reporting in terms of both discretionary accruals and real production activities. Socially responsible firms in environmentally sensitive industries appear to limit earnings management through the use of discretionary accruals, not real activity management. Furthermore, chaebol affiliates with greater CSR activities are not associated with a higher quality of financial reporting for both measures of earnings management.

This finding implies that a firm's characteristics and operation environment distinctively affect the relationship between CSR activities and financial reporting qualities. On the one hand, chaebol affiliates are subject to continuous monitoring by the Korean Supervisory Service and the Korea Fair Trade Commission, and have restrictions on cross-guarantee, debt financing, and financial reporting. These firms already have a higher quality of financial reporting information due to such strict supervision [13], and thus the stakeholders of chaebol affiliates may not have strong incentives to demand more transparent financial reporting. By reflecting such demand of stakeholders, socially 
responsible firms within chaebol affiliates may not exert additional efforts to raise the quality of financial reporting. On the other hand, the majority of environmentally sensitive firms are in the materials industry $(>85 \%)$, which is known to favor the use of discretionary accruals rather than real activity manipulation as a key method for earnings management in the Korean market [14]. Accordingly, the stakeholders within the material industry may not significantly take care of the practice of real activity manipulations compared to the use of discretionary accruals. In fact, socially responsible firms in the material industry turn out to restrict earnings management with the use of discretionary accruals but do not show significant differences in the use of real activity management. Such a heterogeneous result eventually leads to weak support for the hypothesis, predicting a better quality of financial reporting by socially responsible firms.

This paper contributes to the literature in a number of aspects. Most of all, we show the possibility of a higher quality of financial reporting for more socially responsible firms even within emerging markets. This result fills gaps in the literature that have mainly analyzed advanced markets or have adopted a limited sample of international companies. Furthermore, our analysis highlights the importance of a firm's characteristics in shaping the relationship between the firm's degree of social responsibility and the quality of financial reporting. To be specific, the extant studies generally highlight unequivocal effects of CSR practices on the degree of earnings management [1,15]. In contrast, our results suggest that regulatory environments and the preference over earnings management tools are potentially important in determining the relationship between CSR performances and the quality of reported earnings. Furthermore, our evidence in the material industry is consistent with the substitution hypothesis explaining the choice between discretionary accruals and real activity manipulations as the tool of earnings management $[16,17]$. Because the firms in material industry mainly use discretionary accruals as their tools for earnings management, more socially responsible firms in the industry only show a lower level of earnings management in terms of the use of discretionary accruals.

This paper proceeds as follows. Section 2 summarizes the related literature. Section 3 describes our empirical methodologies and data. Section 4 provides the main empirical analysis. Section 5 concludes.

\section{Literature Review and Research Hypotheses}

\subsection{Literature Review}

While researchers have investigated corporations' social concerns for many decades, the academic study on corporate social responsibility has recently become more widespread as Aguinis and Glavas [18] pointed out. The review article of Garriga and Mele [19] argued that a firm's CSR practice can be understood in four different theoretical ways. The first approach considers that the purpose of a corporation is wealth creation and that this is the firm's sole social responsibility. In accordance with this approach, a variety of socially responsible activities are executed if and only if these practices are in line with achieving a corporation's wealth creation. The second group emphasizes the social power of a corporation, and the corporation's responsibility in the political area related to this power. According to this theory, a corporation has to accept social duties and to conduct social corporations in a certain area. The third group argues that corporations have to integrate social demands into their objectives. This group highlights that the sustainability and growth of business depend critically on society and a corporation's social relationships. The fourth approach emphasizes the ethical values in conducting CSR practices. This group argues that a corporation has to accept its social responsibility as an ethical obligation of society above any other demands.

Based on the groups of theories, a large number of empirical studies are conducted to enhance the understanding of a corporation's CSR practices. First of all, it has been widely examined how a corporation's CSR performance is related to its financial performance (See Peloza [20] for review). The way of measuring CSR practices is another branch of empirical literature (See Wood [21] for review). The value enhancing perspectives of CSR practices are also widely analyzed (See Perloza and Shang [22] for review). The relationship between CSR practices and a firm's customer loyalty, reputation, and 
product evaluations have been investigated as well [23-26]. How CSR practices are related to product quality, operating efficiencies, and attractiveness to investors is also widely examined [27-29].

In terms of measuring CSR performances, this study is associated with a branch of literature that adopts the ESG concept (consequently ESG score) to represent a corporation's level of engagement in CSR practices. The report of the United Nations Principles of Responsible Investment first proposes the concept of ESG. The concept of ESG evaluates a corporation's environmental, social, and corporate governance practice. A firm's "environmental performance" points out its effort to reduce resource consumption and pollutant emissions. A firm's "social performance" refers to its practices respecting human rights the responsibility of the product, the quality of employment, and community relations. A firm's "governance performance" points to the rights and responsibilities of the management of a firm toward shareholders.

This study is tightly associated with a strand of literature that attempts is to investigate how a corporation's CSR performance affects its quality of financial reporting [1-3]. Two conflicting views have developed to explain the relationship between CSR performance and the quality of financial reporting. The first view focuses on the self-serving incentives of CEOs in implementing CSR practices. For instance, McWilliams [30] and Hemingway and Maclagan [31] emphasize that CEOs engage in CSR activities for self-serving purposes to advance their careers and reputation, or sometimes to cover up unethical practices such as earnings management. The second view emphasizes that CEOs conduct CSR practices to pursue the ethical demands of stakeholders. Because stakeholders favor more transparent financial reporting, more socially responsible firms tend to have a better quality of financial reporting if the second view is valid.

Recently, many studies have been carried out to examine the effect of a firm's CSR activities on earnings management. The majority of recent studies argue for a better quality of financial reporting for more socially responsible firms, while some studies, such as that of Prior et al. [32], provide opposing evidence. For instance, Chih et al. [3] examine CSR and earnings management based on earnings smoothing, earnings aggressiveness and earnings loss avoidance as earnings management proxies. They find partly supporting evidence for a better quality of financial reporting in the case of earnings smoothing and earnings loss avoidance. Moreover, Kim and Venkatachalam [2] find that the financial reporting quality of sin firms engaged in the tobacco, gambling, and alcohol industries is superior relative to a variety of control groups. Hong et al. [15] use the volatility of discretionary accruals as the measure of earnings and provide supporting evidence for low level of earnings management in socially responsible firms. Scholtens and Kang [10] also find that CSR moderates firms' earnings management within a limited sample of Asian firms.

Our study is most closely related to the analysis of Kim et al. [1]. They provide evidence that CSR practices are negatively associated with a firm's earnings management. They find that more socially responsible firms have a better quality of financial reporting. In fact, their analysis shows that more socially responsible firms use abnormal discretionary accruals limitedly and have a low level of real activity manipulations.

In the Korean market, studies provide supporting evidence for a better quality of financial reporting by more socially responsible firms. For instance, Choi et al. [33] show that a firm is less likely to engage in earnings management if its CSR performance is graded by the Korea Economic Justice Institute (KEJI). Chun and Cho [34] find that CSR strengthens the negative relationship between a differentiation strategy and real activity manipulation, which is also in line with better-quality financial reporting by more socially responsible firms.

It is worthwhile mentioning that these studies are conducted mostly in advanced countries [1,9] or within limited samples of international companies [3,10], particularly in European ones [3]. There are a limited number of researches studying this relationship in developing countries such as Jordaan et al. [35]. These studies generally adopt the measure of CSR performance from international providers such as Bloomberg, which significantly restrict the sample of observations within a developing country. The ESG score used in our analysis covers all corporations listed in the Korea Exchange, which has far 
wider coverage of samples even compared to the KEJI index. Such wide coverage allows us to examine the relationship between CSR performance and the quality of financial reporting comprehensively.

This study is closely related to a strand of literature highlighting firm heterogeneity in determining the relationship between CSR and a variety of corporate policies. For example, Lin et al. [36] argue that each individual firm has to satisfy heterogeneous CSR requirements from its stakeholders depending on the characteristics of firms. Miralles-Quirós et al. [11] highlight that the consideration of environmentally sensitive industries significantly affects the valuation effect of CSR practices. Gavana et al. [37] argue that family firms are more prone than non-family in businesses to resort to CSR disclosure in case of earnings management practices. In the context of the Korean market, Oh et al. [38] focus on how ownership structures, such as the ownership of institutional investors or that of controlling shareholders, affects CSR performances. While Oh et al. [38] examine the significance of governance structure in shaping a corporation's practice, our study mainly focuses on the relationship between CSR performances and the quality of financial reporting.

In Korea, the categorization of chaebol affiliates is shown to have significantly different implications for CSR practices in corporate policies. Yoon et al. [12], for example, argue that the valuation effect of the governance score differs between chaebol and non-chaebol affiliates. Yoon and Lee [39] also emphasize that unlike non-chaebol affiliates, a firm's CSR performance within chaebol affiliates does not have significant effects on the degree of asymmetric information. Park et al. [13] indicate that chaebol affiliates tend to have a higher quality of financial reporting due to the strict monitoring of the Korea Supervisory Service. Within a limited sample firms graded by the KEJI index, Choi et al. [40] find that a negative relationship between CSR and the practice of earnings management weakens within the sample of chaebol affiliates if they adopt the use of discretionary accruals as the measure of earnings management.

\subsection{Research Hypotheses}

As discussed above, there are a number of studies suggesting a higher quality of financial reporting for more socially responsible firms. If CEOs are ethical or try to meet with the ethical demands of their firms' stakeholders, they have incentives to provide more transparent financial reporting. Accordingly, a firm's CSR performance and its financial reporting quality are expected to have a positive relationship. Our first research hypothesis describes this in the following way.

Hypotheses 1 (H1). A firm's CSR performance has a positive relationship with its quality of financial reporting.

However, socially responsible firms within chaebol affiliates may not have strong incentives to provide more transparent financial reporting. As highlighted in Yoon and Lee [39], chaebol affiliates are already under strict supervision by the Korean Supervisory Service and the Korea Fair Trade Commissions. In particular, the disclosure requirements are stricter within chaebol affiliates, as we will discuss the detailed requirements next section. In fact, chaebol affiliates are known to have a high quality of financial reporting, as indicated in Park et al. [13].

To be specific, if a group of firms already produce a high quality of financial reporting, these firms may not enhance additionally the quality of financial reporting even though they are more actively engaged in socially responsible activities. Within the group of firms, their stakeholders may not concern significantly about the quality of financial reporting, which already provides quite transparent information to the stakeholders. More socially responsible firms within this group may not have strong incentive to produce a higher quality of financial reporting due to their stakeholders' limited attentions toward the quality of financial reporting. Thus, more socially responsible firms within chaebol affiliates may not produce a higher quality of financial reporting because their mandatory disclosure requirements make their financial reporting quite transparent. The detailed information about these requirements will be discussed next section.

Hypotheses 2 (H2). A firm's CSR performance within chaebol affiliates is not significantly related to its quality of financial reporting. 
We test these two research hypotheses in later sections.

\section{Methodology and Data}

This section describes the empirical methodology and data sources used for our empirical analysis.

\subsection{Measurements of Earning Quality}

To measure the quality of earnings, we adopt the approach of Kim et al. [1] based on the use of discretionary accruals and real activity manipulations. Their approach relies on the calculation of abnormal components of discretionary accruals and cash flows; the abnormality here refers to unexpected components of these variables. In order to obtain such unexpected components, we initially set up a forecasting regression for each variable and then decompose each variable into predictable and unexpected components based on the estimation results of the forecasting regressions. In the case of discretionary accruals, we use a set of explanatory variables that are widely known to determine the use of discretionary accruals. In the case of real activity manipulations, the forecasting regressions mainly adopt lagged sales to asset ratios and changes in sales to asset ratios because sales critically determine a firm's profit and production costs components. The residuals of these forecasting regressions are considered as abnormal ones, which are closely related to the practices of earnings managements of a corporation.

To be specific, a firm's abnormal discretionary accruals are measured as the residual from the following equation using the discretionary accrual:

$$
\frac{T A_{i, t}}{A_{i, t-1}}=\alpha_{0}\left(\frac{1}{A_{i, t-1}}\right)+\frac{\alpha_{1}\left(\Delta R E V_{i, t}-\Delta R E C_{i, t}\right)}{A_{i, t-1}}+\frac{\alpha_{2} P P E_{i, t}}{A_{i, t-1}}+\frac{\alpha_{3} I B X I_{i, t-1}}{A_{i, t-1}}+\varepsilon_{i, t}
$$

The dependent variable is the total discretionary accruals for a firm, $T A_{i, t}$. The subscripts $i$ and $t$ hereafter represent the entity of a corporation and a specific fiscal year. $\triangle R E V_{i, t}$ captures the change in net revenues and $\triangle R E C_{i, t}$ represents the change in net receivables. The firm's fixed capital $\left(P P E_{i, t}\right)$ and operating income $\left(I B X I_{i, t-1}\right)$ are also included to estimate the abnormal level of discretionary accruals. The residual components of the regressions are considered as abnormal discretionary accruals. For instance, a firm is considered to manage earnings more significantly if the absolute value of abnormal components is larger.

To measure a firm's real activity manipulation in financial reporting, we adopt the following equations for the construction of abnormal cash flows from operations (AB_CFO) and abnormal discretionary expenses (AB_EXP). The AB_CFO and AB_EXP are measured by the residuals of Equations (2) and (3).

$$
\begin{gathered}
\frac{\mathrm{CFO}_{i, t}}{A_{i, t-1}}=\alpha_{0}+\alpha_{1}\left(\frac{1}{A_{i, t-1}}\right)+\alpha_{2}\left(\frac{S_{i, t}}{A_{i, t-1}}\right)+\alpha_{3}\left(\frac{\Delta S_{i, t}}{A_{i, t-1}}\right)+\varepsilon_{i, t .} \\
\frac{\operatorname{DISEXP}_{i, t}}{A_{i, t-1}}=\alpha_{0}+\alpha_{1}\left(\frac{1}{A_{i, t-1}}\right)+\alpha_{2}\left(\frac{S_{i, t-1}}{A_{i, t-1}}\right)+\varepsilon_{i, t}
\end{gathered}
$$

The dependent variables are cash flow from operations $\left(C F O_{i, t}\right)$ and the discretionary expenses that are defined as the sum of $R \& D$, advertising and other indirect expenses $\left(D I S E X P_{i, t}\right)$. The variable $S_{i, t}$ represents net sales and $\Delta S_{i, t}$ indicates the changes in net sales from the previous fiscal year. All of the variables are normalized by the lagged value of book assets.

Finally, the abnormal production cost (AB_PROD) is derived from the abnormal level of production cost (PROD), which is defined as the sum of cost of goods sold (COGS) and changes in inventory $(\triangle \mathrm{INV})$. That is, $P R O D_{i, t}=C O G S_{i, t}+\Delta I N V_{i, t} . C O G S_{i, t}$ and $\Delta I N V_{i, t}$ are modelled by the following Equations (4) and (5), respectively. As a result, the abnormal production cost can be estimated as a residual of Equation (6). 


$$
\begin{gathered}
\frac{\operatorname{COGS}_{i, t}}{A_{i, t-1}}=\alpha_{0}+\alpha_{1}\left(\frac{1}{A_{i, t-1}}\right)+\alpha_{2}\left(\frac{S_{t}}{A_{i, t-1}}\right)+\varepsilon_{i, t .} \\
\frac{\Delta I N V_{i, t}}{A_{i, t-1}}=\alpha_{0}+\alpha_{1}\left(\frac{1}{A_{i, t-1}}\right)+\alpha_{2}\left(\frac{\Delta S_{i, t}}{A_{i, t-1}}\right)+\alpha_{3}\left(\frac{\Delta S_{i, t-1}}{A_{i, t-1}}\right)+\varepsilon_{i, t}
\end{gathered}
$$

Finally, we derive AB_PROD as the residual of Equation (7)

$$
\frac{P R O D_{i, t}}{A_{i, t-1}}=\alpha_{0}+\alpha_{1}\left(\frac{1}{A_{i, t-1}}\right)+\alpha_{2}\left(\frac{S_{i, t}}{A_{i, t-1}}\right)+\alpha_{3}\left(\frac{\Delta S_{i, t}}{A_{i, t-1}}\right)+\alpha_{4}\left(\frac{\Delta S_{i, t-1}}{A_{i, t-1}}\right)+\varepsilon_{i, t}
$$

The residuals of Equations (2), (3) and (6) are considered to have close associations with the practice of earnings management. However, the signs of these abnormal components matter in detecting the practice of earnings management unlike the use of abnormal discretionary accruals. The detailed information about the sign of abnormal cash flow variables will be discussed next section.

\subsection{Empirical Model and Data}

We now turn to describe our main empirical model to test the relationship between CSR performance and the quality of financial reporting.

$$
\begin{aligned}
& \text { Quality }_{t}=\alpha_{0}+\alpha_{1} E S G \_S C O R E_{t}+\alpha_{2} S I Z E_{\mathrm{t}-1}+\alpha_{3} M B_{\mathrm{t}-1}+\alpha_{4} A D J_{-} R O A_{t-1}+ \\
& \alpha_{5} L E V_{t-1}+\alpha_{6} E O_{t}+\alpha_{7} R D \_I N T_{t}+\alpha_{8} A D \_I N D \_I N T_{t}+ \\
& \alpha_{9} L N \_F I R M \_A G E_{t}+\text { Industrydummy }+\varepsilon_{t}
\end{aligned}
$$

The dependent variable of quality represents the quality of financial reporting. The proxy variables for the quality of financial reporting are as follows. We use the absolute value of the abnormal discretionary accruals (ABS_DA) and its positive (P_DA)/negative (N_DA) components to measure a CEO's earnings management with the use of discretionary accruals. The abnormal cash flow (AB_CFO), the abnormal production cost (AB_PROD), the abnormal discretionary expense (AB_EXP) and its combination (COMB_RAM) variables are used to proxy the quality of financial reporting in terms of real activity manipulation.

The Equation (7) is estimated by using cross-sectional regression models with the ordinary least square method. Our empirical hypotheses are cross-sectional ones that examines the relationship between a firm's ESG score and its degree of earnings management. Hence, by adopting the estimation strategy of Kim et al. [1], we estimate cross-sectional regression models that mainly focuses on the variation across corporations rather than the time-series variation within a corporation. By following the spirit of such cross-sectional models, we also exclude the year-fixed effect terms in the Equation (7). The inclusion of the year-fixed effect term does not alter our main results while we do not report them. Such robustness of our results is natural one because we consider a relatively short time period of sample from 2010 to 2015.

Note that our Equation (7) uses the quality of financial reporting as the dependent variables in line with the extant literature testing the cross-sectional implications of CSR performance on the practice of earnings management $[1,15]$. Because these studies pay attention to how the variation of CSR performance affects the quality of financial reporting, the measure of CSR performance is used as the independent variable and the quality of financial reporting is adopted as the dependent variable. Such specification contrasts some studies such as Choi et al. [39], which mainly examine the determinants of CSR performances and include the degree of earnings management as an explanatory variable. In their study, the CSR performance is used as the dependent variable and the level of earnings management is considered as the independent variable in opposition to our empirical specification.

$\mathrm{H} 1$ predicts negative associations between CSR performances and the absolute value of discretionary accruals. In other words, a firm with a better CSR performance exhibits a less significant use 
of an abnormal level of discretionary accruals. Based on the same logic, we predict a negative (positive) association of CSR performances with the positive (negative) values of abnormal discretionary accruals.

$\mathrm{H} 1$ also expects that a firm's CSR performance will be positively related to the abnormal level of cash flow and abnormal discretionary expenses [1]. If a CEO tries to manage earnings by adopting a price discount policy or expanding accounts receivables, we expect a low level of cash flow compared to the predicted level. Similarly, a CEO with income-increasing incentives may reduce R\&D expenses and other indirect expenses, including advertising costs. In contrast, $\mathrm{H} 1$ predicts a negative association between CSR performance and abnormal production costs. If a CEO engages in earnings management via overproduction, the abnormal production cost increases significantly. As a result, the COMB_RAM, which is the sum of $A B \_C F O$ and AB_EXP less AB_PROD, is expected to show a positive relationship with a firm's CSR performance.

$\mathrm{H} 1$ can be tested by examining the sign and statistical significance of the coefficient on the ESG score, $\alpha_{1}$. The ESG score is defined as the sum of the environmental, social and governance score published by the Korean Corporate Governance Service. The KCGS assesses a corporation's environmental performance by using the following categories: the degree of pollutant emissions, the adoption of green marketing, the production of environmentally friendly goods, and the level of clean production. A firm's social performance is assessed based on the following categories: the degree of sustainable management practices, the working conditions of employees, the firm's relationship with labor unions, the management toward business ethics, and the development of human resources. A corporation's governance score is evaluated based on the following categories: the degree of investor protections, the quality of information disclosure, the effectiveness of board structure, the structure of managerial compensation, the quality of auditing and the healthiness of distribution policy. Each E/S/G score is the sum of the scores for such categories. The total ESG score is calculated as the sum of the environmental, social and governance scores.

In sum, a significantly negative coefficient on the ESG score, $\alpha_{1}$ in Equation (7) supports $\mathrm{H} 1$ when we examine the absolute value of abnormal discretionary accruals, the positive value of abnormal discretionary accruals, and the abnormal production costs as the dependent variable of the equation. In contrast, a significantly positive coefficient on the ESG score, $\alpha_{1}$ in Equation (7) argues for $\mathrm{H} 1$ in case of the negative value of abnormal discretionary accruals, abnormal cash flow, abnormal expenses, and combined RAM as the dependent variable of Equation (7).

It is noteworthy mentioning that the existing studies with regard to CSR practices in the Korean financial market, mainly used the KEJI index. However, the KEJI index only covers only 200 corporations per year, which has a far narrower sample coverage compared to the ESG score published by the Korean Corporate Governance Services. Thus, our study is under a less significant influence of sample selection biases compared to the extant studies using the KEJI index. Such a comprehensive coverage of evaluation for CSR performances is hardly achievable even in the analysis of other developing countries that largely rely on international grade providers such as Bloomberg [10,35].

We construct the set of control variables in the following way. We use the items from a firm's financial statements such as the book asset size, the amount of debt obligations, the use of equity financing, investments in R\&D and advertising activities, and the firm's age. The industry categorization is used as well, which also significantly affect the choice of earnings management tools and the degree of earnings management. The variable of SIZE is a firm's decile of book asset value size in the firm size distribution for each year. The industry-adjusted ROA (ADJ_ROA) is the ratio of income before extraordinary items and the lagged book value of assets adjusted by the two-digit GICS code, an industry categorization code used in the Korean financial market. A firm's leverage, LEV, is defined as a firm's total long-term debt obligations dived by total book asset values. A firm's engagement in equity offerings, EO, is an indicator variable if it offers equity for the fiscal year. The R\&D intensity of a corporation, RD_INT, is defined as a firm's R\&D expense scaled by its net sales for the fiscal year. The advertising intensity for each industry, AD_IND_INT, is the ratio of advertising expense and total 
sales adjusted for the two-digit SIC code industry for the year. A firm's age, LN_FIRM_AGE, is the natural logarithm of $(1+$ age of firm).

We consider the group of industries related to the energy, materials, and utility sectors as environmentally sensitive ones based on the GICS code. The energy sector indicates energy equipment/ services and oil/gas/consumable fuel industries. The materials sector refers to the chemicals, construction materials, metals and mining industries. The utility industry refers to companies that produce electricity, gas, water, and renewable energies.

We categorize specific business groups as chaebols by using the guideline of the Financial Supervisory Service of Korea from 2010 to 2015. According to the Financial Supervisory Service of Korea, a chaebol is a business group with total book assets over 2 trillion won, and is operated by a specific controlling shareholder or the members of the founder family.

The firms that are affiliated in the group of chaebol are under more severe restrictions on their major corporate decisions such as financing, governance structure, and disclosure policies. In terms of financing policy, cross-holdings and cross-debt guarantees are strictly banned among chaebol affiliates. Unfair supports and business transactions among the chaebol affiliates are restricted as well. In terms of governance structure, circular shareholdings are prohibited within the chaebol affiliates, and chaebol affiliates that belong to financial service industry have limited voting power for the other firms within the same affiliation to a chaebol. In terms of disclosure and auditing policies, the chaebol affiliates have responsibility to report their board structure, controlling shareholders, and large business transactions periodically. The chaebol affiliates are required to disclose their financial and other major transactions even before their initial public offerings. Accordingly, the chaebol affiliates are considered to provide more transparent information related to financial policies, governance structures, and business transactions.

The second hypothesis, $\mathrm{H} 2$, can be tested based on the statistical significance of the coefficient on the ESG score, $\alpha_{1}$ within chaebol affiliates. The hypothesis is that the coefficient $\alpha_{1}$ is not significantly related to the proxy variables for earnings management if we use the sub-sample of chaebol affiliates. This non-significance may not depend on whether we use the abnormal level of discretionary accruals or abnormal proxy variables related to real activity manipulations.

\subsection{Descriptive Statistics}

Table 1 describes the categories of industry used in our empirical examination. The table documents GICS industry code, the number of firm-year observation and its percentage in the entire sample, and the indication of environmentally sensitive industries (ESI). The table indicates that the total number of the sample is 3779 . The table also points out that the materials industry explains almost all sample-firm year observations belonging to environmentally sensitive industries. More than $85 \%$ of the environmentally sensitive industries consist of the firm-year observations from the materials industry, which significantly affects our empirical estimation results in later sections.

Table 1. Distribution of Firms by Industry.

\begin{tabular}{cccccc}
\hline Industry & Two-Digit GICS & Freq. & Percent & Cum. & ESI \\
\hline Energy & 10 & 72 & 1.91 & 1.91 & YES \\
Materials & 15 & 888 & 23.50 & 25.41 & YES \\
Industrials & 20 & 907 & 24.00 & 49.41 & NO \\
Consumer Discretionary & 25 & 874 & 23.13 & 72.54 & NO \\
Consumer Staples & 30 & 288 & 7.62 & 80.16 & NO \\
Health Care & 35 & 262 & 6.93 & 87.08 & NO \\
Information Technology & 45 & 388 & 10.27 & 97.35 & NO \\
Utilities & 55 & 100 & 2.65 & 100 & YES \\
\hline Total & & 3779 & 100 & 100 & \\
\hline
\end{tabular}


Table 2 presents the summary statistics results for our variables of interests. The variables include the ESG score, the proxy variables for financial reporting quality and the set of control variables. The environmental score, social score and governance score are separately included as well in the table. Information related to the environmentally sensitive industries and chaebol affiliation is also documented. The average value and standard deviation for each variable is reported. The minimum, 1st quartile, 2nd quartile, 3rd quartile and maximum values for each variable distribution are reported as well.

Table 2. Descriptive Statistics.

\begin{tabular}{|c|c|c|c|c|c|c|c|c|}
\hline Variable & $\mathbf{N}$ & Mean & SD & Min & $25 \%$ & Median & $75 \%$ & Max \\
\hline ESG SCORE & 3774 & 282.0 & 115.2 & 62 & 198 & 273 & 338.1 & 679.3 \\
\hline ENV SCORE & 3774 & 100.9 & 65.68 & 0 & 41 & 103 & 145 & 252.3 \\
\hline SOC SCORE & 3774 & 89.16 & 49.34 & 21 & 57 & 77 & 107 & 250 \\
\hline GOV SCORE & 3774 & 91.92 & 28.11 & 31 & 72 & 92 & 108 & 177 \\
\hline DA & 3774 & -0.358 & 6.432 & -21.62 & -3.680 & -0.253 & 2.996 & 19.63 \\
\hline ABS_DA & 3774 & 4.714 & 4.807 & 0.0585 & 1.484 & 3.295 & 6.146 & 26.54 \\
\hline POSITIVE_DA & 1815 & 4.517 & 4.571 & 0.0467 & 1.439 & 3.141 & 5.909 & 24.79 \\
\hline NEGATIVE_DA & 1959 & -4.892 & 4.998 & -27.58 & -6.354 & -3.506 & -1.515 & -0.0730 \\
\hline AB_CFO & 3774 & 0.0334 & 6.347 & -17.72 & -3.688 & -0.126 & 3.691 & 19.14 \\
\hline AB_PROD & 3774 & 0.139 & 11.34 & -45.77 & -4.675 & 0.784 & 5.927 & 31.17 \\
\hline AB_EXP & 3774 & -0.0653 & 2.113 & -4.718 & -0.930 & -0.402 & 0.336 & 9.960 \\
\hline COMB_RAM & 3774 & -0.149 & 16.17 & -43.18 & -9.367 & -1.156 & 8.053 & 61.05 \\
\hline SIZE & 3774 & 19.07 & 1.682 & 16.29 & 17.82 & 18.72 & 19.97 & 23.81 \\
\hline MB & 3774 & 1.076 & 1.002 & 0.155 & 0.478 & 0.768 & 1.264 & 6.052 \\
\hline ADJ_ROA & 3774 & 0.0299 & 0.0734 & -0.286 & 0.00456 & 0.0299 & 0.0652 & 0.232 \\
\hline LEV & 3774 & 0.484 & 0.196 & 0.0992 & 0.325 & 0.495 & 0.628 & 0.926 \\
\hline EO & 3774 & 0.077 & 0.266 & 0 & 0 & 0 & 0 & 1 \\
\hline RD_INT & 3774 & 0.007 & 0.016 & 0 & 0 & 0.001 & 0.007 & 0.090 \\
\hline AD_IND_INT & 3774 & 0.012 & 0.013 & 0.001 & 0.002 & 0.003 & 0.022 & 0.0415 \\
\hline LN_FIRM_AGE & 3774 & 3.528 & 0.663 & 1.386 & 3.401 & 3.738 & 3.951 & 4.466 \\
\hline CHAEBOL & 3672 & 0.253 & 0.435 & 0 & 0 & 0 & 1 & 1 \\
\hline ESI & 3774 & 0.281 & 0.449 & 0 & 0 & 0 & 1 & 1 \\
\hline
\end{tabular}

Table 2 provides significant variations in the ESG score and the proxy variables related to the use of discretionary accruals and real activity manipulations. For instance, the mean of the ESG score is 282 and its standard deviation equals 115, which shows a significant variation in CSR performances in the Korean financial market. In the case of absolute abnormal discretionary accruals, the mean and standard deviation of the variable are 4.7 and 4.8, respectively. Other proxy variables for the quality of financial reporting also show substantial variations, which helps us examine economically meaningful relationships between CSR performances and the quality of financial reporting.

Table 2. also shows a generally right-skewed distribution of each variable. The mean of almost all variables is greater than its corresponding median values. One notable exception is the logarithm of firm age variable. The variable's median value is 3.738, which is larger than its mean value, 3.528. This pattern implies a large number of young firms in the sample observations, which is in line with the survivorship patterns of firms.

Table 3 provides the pairwise correlation coefficients among our variables of interests. The table includes the ESG score, and the proxy variables for the quality of financial reporting with regard to the use of discretionary accruals and real activity manipulations. The set of control variables in the estimations are also reported in line with Table 2.

Table 3 indicates that the correlation coefficient between the ESG score and the proxy variables for the quality financial reporting support our first empirical hypothesis, H1. For instance, the ESG score is negatively related to the absolute value of abnormal discretionary accruals. The ESG score is positively associated with the abnormal cash flow and the abnormal discretionary expense, but is negatively related to the abnormal production cost. All of these coefficients are statistically significant and consistent with the hypothesis predicting less significant earnings management by more socially responsible firms. 
Table 3. Correlation Coefficients.

\begin{tabular}{|c|c|c|c|c|c|c|c|}
\hline Variable & SCORE ESG & ABS_DA & AB_CFO & AB_PROD & AB_EXP & COMB_RAM & SIZE \\
\hline SCORE ESG & 1.000 & & & & & & \\
\hline ABS_DA & $\begin{array}{c}-0.098^{* * *} \\
0.000\end{array}$ & 1.000 & & & & & \\
\hline AB_CFO & $\begin{array}{c}0.033 \text { ** } \\
0.040\end{array}$ & $\begin{array}{l}-0.026 \\
0.116\end{array}$ & 1.000 & & & & \\
\hline AB_PROD & $\begin{array}{c}-0.052^{* * *} \\
0.001\end{array}$ & $\begin{array}{c}0.038^{* *} \\
0.021\end{array}$ & $\begin{array}{c}-0.347^{* * *} \\
0.000\end{array}$ & 1.000 & & & \\
\hline AB_EXP & $\begin{array}{c}0.150^{* * *} \\
0.000\end{array}$ & $\begin{array}{l}-0.004 \\
0.816\end{array}$ & $\begin{array}{c}0.120^{* * *} \\
0.000\end{array}$ & $\begin{array}{c}-0.465^{* * *} \\
0.000\end{array}$ & 1.000 & & \\
\hline COMB_RAM & $\begin{array}{c}0.068^{* * *} \\
0.000\end{array}$ & $\begin{array}{c}-0.037^{* *} \\
0.023\end{array}$ & $\begin{array}{c}0.652^{* * *} \\
0.000\end{array}$ & $\begin{array}{c}-0.922^{* * *} \\
0.000\end{array}$ & $\begin{array}{c}0.507^{* * *} \\
0.000\end{array}$ & 1.000 & \\
\hline SIZE & $\begin{array}{c}0.530 * * * \\
0.000\end{array}$ & $\begin{array}{c}-0.1422^{* * *} \\
0.000\end{array}$ & $\begin{array}{l}0.002 \\
0.909\end{array}$ & $\begin{array}{c}-0.008 \\
0.610\end{array}$ & $\begin{array}{c}0.082^{* * *} \\
0.000\end{array}$ & $\begin{array}{l}0.017 \\
0.298\end{array}$ & 1.000 \\
\hline MB & $\begin{array}{c}0.129 * * * \\
0.000\end{array}$ & $\begin{array}{c}0.114^{* * *} \\
0.000\end{array}$ & $\begin{array}{c}0.127^{* * *} \\
0.000\end{array}$ & $\begin{array}{c}-0.180 * * * \\
0.000\end{array}$ & $\begin{array}{c}0.225^{* * *} \\
0.000\end{array}$ & $\begin{array}{c}0.199 * * * \\
0.000\end{array}$ & $\begin{array}{c}0.031 \text { * } \\
0.058\end{array}$ \\
\hline ADJ_ROA & $\begin{array}{c}0.092^{* * *} \\
0.000\end{array}$ & $\begin{array}{c}-0.153^{* * *} \\
0.000\end{array}$ & $\begin{array}{c}0.237^{* * *} \\
0.000\end{array}$ & $\begin{array}{c}-0.214^{* * *} \\
0.000\end{array}$ & $\begin{array}{c}0.093^{* * *} \\
0.000\end{array}$ & $\begin{array}{c}0.258^{* * *} \\
0.000\end{array}$ & $\begin{array}{c}0.169^{* * *} \\
0.000\end{array}$ \\
\hline LEV & $\begin{array}{c}0.164^{* * *} \\
0.000\end{array}$ & $\begin{array}{c}0.111^{* * *} \\
0.000\end{array}$ & $\begin{array}{c}-0.183^{* * *} \\
0.000\end{array}$ & $\begin{array}{c}0.165^{* * *} \\
0.000\end{array}$ & $\begin{array}{c}-0.098^{* * *} \\
0.000\end{array}$ & $\begin{array}{c}-0.206^{* * *} \\
0.000\end{array}$ & $\begin{array}{c}0.263^{* * *} \\
0.000\end{array}$ \\
\hline EO & $\begin{array}{c}-0.065^{* * *} \\
0.000\end{array}$ & $\begin{array}{c}0.142^{* * *} \\
0.000\end{array}$ & $\begin{array}{c}-0.101^{* * *} \\
0.000\end{array}$ & $\begin{array}{c}0.069^{* * *} \\
0.000\end{array}$ & $\begin{array}{c}-0.013 \\
0.433\end{array}$ & $\begin{array}{c}-0.092^{* * *} \\
0.000\end{array}$ & $\begin{array}{c}-0.083^{* * *} \\
0.000\end{array}$ \\
\hline RD_INT & $\begin{array}{c}0.090^{* * *} \\
0.000\end{array}$ & $\begin{array}{l}-0.019 \\
0.243\end{array}$ & $\begin{array}{c}0.033^{* *} \\
0.041\end{array}$ & $\begin{array}{c}-0.088^{* * *} \\
0.000\end{array}$ & $\begin{array}{c}0.415^{* * *} \\
0.000\end{array}$ & $\begin{array}{c}0.129^{* * *} \\
0.000\end{array}$ & $\begin{array}{c}-0.004 \\
0.819\end{array}$ \\
\hline AD_IND_INT & $\begin{array}{c}-0.166^{* * *} \\
0.000\end{array}$ & $\begin{array}{l}-0.006 \\
0.701\end{array}$ & $\begin{array}{c}-0.010 \\
0.528\end{array}$ & $\begin{array}{l}0.007 \\
0.649\end{array}$ & $\begin{array}{c}-0.053^{* * *} \\
0.001\end{array}$ & $\begin{array}{c}-0.017 \\
0.306\end{array}$ & $\begin{array}{c}-0.115^{* * *} \\
0.000\end{array}$ \\
\hline LN_FIRM_AGE & $\begin{array}{c}-0.021 \\
0.195\end{array}$ & $\begin{array}{c}-0.029 * \\
0.071\end{array}$ & $\begin{array}{c}-0.034^{* *} \\
0.038\end{array}$ & $\begin{array}{c}0.100^{* * *} \\
0.000\end{array}$ & $\begin{array}{c}-0.073^{* * *} \\
0.000\end{array}$ & $\begin{array}{c}-0.096^{* * *} \\
0.000\end{array}$ & $\begin{array}{l}0.004 \\
0.823\end{array}$ \\
\hline Variable & MB & ADJ_ROA & LEV & EO & RD_INT & AD_IND_INT & $\overline{\text { LN_FIRM_AGE }}$ \\
\hline MB & 1.000 & & & & & & \\
\hline ADJ_ROA & $\begin{array}{c}0.124^{* * *} \\
0.000\end{array}$ & 1.000 & & & & & \\
\hline LEV & $\begin{array}{c}0.029 * \\
0.076\end{array}$ & $\begin{array}{c}-0.329^{* * *} \\
0.000\end{array}$ & 1.000 & & & & \\
\hline EO & $\begin{array}{c}0.137^{* * *} \\
0.000\end{array}$ & $\begin{array}{c}-0.294^{* * *} \\
0.000\end{array}$ & $\begin{array}{c}0.155^{* * *} \\
0.000\end{array}$ & 1.000 & & & \\
\hline RD_INT & $\begin{array}{c}0.199 * * * \\
0.000\end{array}$ & $\begin{array}{l}0.011 \\
0.487\end{array}$ & $\begin{array}{c}-0.114^{* * *} \\
0.000\end{array}$ & $\begin{array}{c}0.028 * \\
0.090\end{array}$ & 1.000 & & \\
\hline AD_IND_INT & $\begin{array}{c}0.092^{* * *} \\
0.000\end{array}$ & $\begin{array}{l}0.026 \\
0.104\end{array}$ & $\begin{array}{c}-0.130 * * * \\
0.000\end{array}$ & $\begin{array}{l}0.012 \\
0.466\end{array}$ & $\begin{array}{c}0.203^{* * *} \\
0.000\end{array}$ & 1.000 & \\
\hline LN_FIRM_AGE & $\begin{array}{c}-0.165^{* * *} \\
0.000\end{array}$ & $\begin{array}{c}-0.090^{* * *} \\
0.000\end{array}$ & $\begin{array}{c}-0.018 \\
0.280\end{array}$ & $\begin{array}{c}-0.034^{* *} \\
0.034\end{array}$ & $\begin{array}{c}-0.004 \\
0.811\end{array}$ & $\begin{array}{c}-0.019 \\
0.236\end{array}$ & 1.000 \\
\hline
\end{tabular}

The symbols ${ }^{* * *}, * * *{ }^{*}$ represent significance at the $0.01,0.05$ and 0.1 level, respectively.

\section{Empirical Results}

\subsection{Estimation Results}

Table 4 examines how a firm's engagement in socially responsible activities affect the quality of financial reporting by analyzing the entire sample of firms in the Korean financial market. The first three columns investigate how a firm's CSR affects the use of discretionary accruals by using the absolute value of abnormal accruals and by splitting the samples with positive and negative abnormal accruals. The last four columns examine the relationship between CSR activity and production cost management by using abnormal cash flow, abnormal production cost, abnormal expenses and their combinations. The control variables include a firm's size, market to book ratio, ROA, leverage, equity offering indicator, R\&D intensity, advertising intensity and age. The industry fixed effect is controlled as well. 
Table 4. CSR and Financial Reporting Quality.

\begin{tabular}{|c|c|c|c|c|c|c|c|}
\hline Variable & ABS_DA & POSITIVE_DA & NEGATIVE_DA & AB_CFO & AB_PROD & AB_EXP & COMB_RAM \\
\hline $\mathrm{ESG} \mathrm{SCORE}_{\mathrm{t}}$ & $\begin{array}{c}-0.247^{* * *} \\
(0.0792)\end{array}$ & $\begin{array}{c}-0.449^{* * *} \\
(0.112)\end{array}$ & $\begin{array}{l}0.0633 \\
(0.112)\end{array}$ & $\begin{array}{c}0.120 \\
(0.104)\end{array}$ & $\begin{array}{l}-0.279 \\
(0.186)\end{array}$ & $\begin{array}{c}0.0978^{* * *} \\
(0.0310)\end{array}$ & $\begin{array}{l}0.499 * \\
(0.259)\end{array}$ \\
\hline $\mathrm{MB}_{\mathrm{t}-1}$ & $\begin{array}{l}0.611^{* * *} \\
(0.0808)\end{array}$ & $\begin{array}{c}0.722^{* * *} \\
(0.114)\end{array}$ & $\begin{array}{c}-0.484^{* * *} \\
(0.114)\end{array}$ & $\begin{array}{c}0.739 * * * \\
(0.107)\end{array}$ & $\begin{array}{c}-1.740 * * * \\
(0.189)\end{array}$ & $\begin{array}{l}0.317^{* * *} \\
(0.0316)\end{array}$ & $\begin{array}{c}2.673^{* * *} \\
(0.264)\end{array}$ \\
\hline $\operatorname{LEV}_{t-1}$ & $\begin{array}{c}2.417^{* * *} \\
(0.445)\end{array}$ & $\begin{array}{c}1.613^{* * *} \\
(0.611)\end{array}$ & $\begin{array}{c}-2.980 * * * \\
(0.649)\end{array}$ & $\begin{array}{c}-4.295 * * * \\
(0.588)\end{array}$ & $\begin{array}{c}7.434^{* * *} \\
(1.044)\end{array}$ & $\begin{array}{c}-1.157^{* * *} \\
(0.174)\end{array}$ & $\begin{array}{c}-13.30^{* * *} \\
(1.455)\end{array}$ \\
\hline $\mathrm{EO}_{\mathrm{t}}$ & $\begin{array}{c}1.270 * * * \\
(0.302)\end{array}$ & $\begin{array}{c}1.296^{* * *} \\
(0.398)\end{array}$ & $\begin{array}{c}-1.296^{* * *} \\
(0.457)\end{array}$ & $\begin{array}{c}-1.133 * * * \\
(0.399)\end{array}$ & $\begin{array}{l}1.336 * \\
(0.709)\end{array}$ & $\begin{array}{l}-0.109 \\
(0.118)\end{array}$ & $\begin{array}{c}-2.596^{* * *} \\
(0.988)\end{array}$ \\
\hline AD_IND_INT $\mathbf{t}$ & $\begin{array}{l}2106^{*} \\
(1084)\end{array}$ & $\begin{array}{c}1287 \\
(1474)\end{array}$ & $\begin{array}{l}-2851 * \\
(1585)\end{array}$ & $\begin{array}{l}-651.9 \\
(1431)\end{array}$ & $\begin{array}{l}21.55 \\
(2541)\end{array}$ & $\begin{array}{c}-1699 * * * \\
(424.0)\end{array}$ & $\begin{array}{l}-3135 \\
(3542)\end{array}$ \\
\hline LN_FIRM_AGE $t$ & $\begin{array}{c}-0.0722 \\
(0.117)\end{array}$ & $\begin{array}{c}-0.0977 \\
(0.162)\end{array}$ & $\begin{array}{l}0.0466 \\
(0.167)\end{array}$ & $\begin{array}{c}-0.0332 \\
(0.154)\end{array}$ & $\begin{array}{c}1.129^{* * *} \\
(0.274)\end{array}$ & $\begin{array}{c}-0.119 * * * \\
(0.0457)\end{array}$ & $\begin{array}{c}-1.387^{* * *} \\
(0.381)\end{array}$ \\
\hline Industry dummy & Included & Included & Included & Included & Included & Included & Included \\
\hline Observations & 3773 & 1815 & 1958 & 3773 & 3773 & 3773 & 3773 \\
\hline R-squared & 0.085 & 0.080 & 0.095 & 0.086 & 0.096 & 0.275 & 0.137 \\
\hline
\end{tabular}

Note: Standard errors in parentheses. ${ }^{* * *},{ }^{* *},{ }^{*}$ represent significance at the $0.01,0.05$ and 0.1 level, respectively.

Table 4 provides weak evidence arguing for the first hypothesis. In the case of discretionary accruals, the estimation results generally provide supporting evidence for a higher quality of financial reporting by socially responsible firms. The coefficients on the absolute and positive values of abnormal accruals are significantly negative, in line with H1. While it is not statistically significant, the sign of coefficient on the negative accruals is positive, consistent with $\mathrm{H} 1$.

The coefficients on the ESG score do not strongly support the hypothesis in the case of real activity manipulation. The coefficient on the ESG score is significantly positive with abnormal expense, consistent with H1. However, the coefficients do not have statistical significance in the case of abnormal cash flow and abnormal production costs cases, while their estimated signs are still in line with H1.

The sign of coefficients on other control variables are generally consistent with the extant literature. In the regression with the absolute value of discretionary accruals, the size variable has a significantly negative coefficient, which implies a better quality of financial reporting by large firms. A firm's leverage improves the quality of financial reporting. Young firms tend to have a poor quality of financial reporting, while the coefficient itself is statistically insignificant. All of these coefficients are in line with the U.S. evidence of Kim et al. [1]. In contrast, a firm's R\&D intensity appears to increase the transparency of financial reporting, which is not well aligned with the U.S. evidence [1]. This might be due to the fact that unlike the U.S. corporations, large manufacturing firms like Samsung Electronics tend to have a high intensity of R\&D.

In the case of combined RAM, the return on asset has a significantly positive coefficient, which implies a better quality of financial reporting in terms of real activity manipulation. A firm's age and leverage have significantly negative coefficients. All of the coefficients are in line with the U.S. evidence in terms of real activity manipulation [1]. Yet, a higher R\&D intensity still improves the quality of financial reporting in the Korean market, similar to the case of discretionary accruals. This finding is not well aligned with the U.S. evidence.

To investigate a potential reason behind the weak evidence reported in Table 4, we split the entire sample into ESI and non-ESI industries. As highlighted in Yoon et al. [12], there may exist differences between ESI and non-ESI industries about how the effects of CSR activities affect corporate policies in the Korean market. In Table 5, we firstly examine the group of firms belonging to ESI. Similar to 
Table 4, we initially examine the proxy variables related to the decision on discretionary accruals and investigate production cost management variables next. Table 5 has the same set of control variables as Table 4 and considers the industry fixed effect as well.

Table 5 still provides weak evidence for the relationship between the information quality of financial reporting and a firm's active engagement in socially responsible activities. The coefficients on ESG scores generally support a higher quality for socially responsible firms, especially for the use of absolute and positive values of discretionary accruals. However, the ESG score is rather positively related to abnormal cash flow generation and negatively related to abnormal production costs, which implies a poorer quality of financial reporting for firms with greater CSR activities. The ESG score does not show a statistically significant relationship with abnormal expenses. All of the coefficients argue against a higher quality of financial reporting for socially responsible firms.

Table 5. CSR and Financial Reporting Quality: Environmentally Sensitive Industries.

\begin{tabular}{|c|c|c|c|c|c|c|c|}
\hline Variable & ABS_DA & POSITIVE_DA & NEGATIVE_DA & AB_CFO & AB_PROD & AB_EXP & COMB_RAM \\
\hline $\mathbf{M B}_{\mathrm{t}-1}$ & $\begin{array}{c}0.617^{* * *} \\
(0.169)\end{array}$ & $\begin{array}{c}0.878^{* * *} \\
(0.243)\end{array}$ & $\begin{array}{l}-0.338 \\
(0.238)\end{array}$ & $\begin{array}{c}0.841 * * * \\
(0.236)\end{array}$ & $\begin{array}{c}-1.599 * * * \\
(0.282)\end{array}$ & $\begin{array}{c}0.0534 \\
(0.0350)\end{array}$ & $\begin{array}{c}2.598^{* * *} \\
(0.462)\end{array}$ \\
\hline ADJ_ROA $_{t-1}$ & $\begin{array}{c}2.138 \\
(2.169)\end{array}$ & $\begin{array}{c}2.197 \\
(3.022)\end{array}$ & $\begin{array}{l}-3.430 \\
(3.140)\end{array}$ & $\begin{array}{c}18.67^{* * *} \\
(3.026)\end{array}$ & $\begin{array}{c}-28.04^{* * *} \\
(3.613)\end{array}$ & $\begin{array}{c}1.269^{* * *} \\
(0.449)\end{array}$ & $\begin{array}{l}49.02^{* * *} \\
(5.922)\end{array}$ \\
\hline $\operatorname{LEV}_{t-1}$ & $\begin{array}{c}3.479 * * * \\
(0.816)\end{array}$ & $\begin{array}{c}2.757^{* *} \\
(1.141)\end{array}$ & $\begin{array}{c}-3.728^{* * *} \\
(1.169)\end{array}$ & $\begin{array}{c}-4.308^{* * *} \\
(1.138)\end{array}$ & $\begin{array}{c}2.776^{* *} \\
(1.359)\end{array}$ & $\begin{array}{c}0.193 \\
(0.169)\end{array}$ & $\begin{array}{c}-6.915^{* * *} \\
(2.228)\end{array}$ \\
\hline $\mathrm{EO}_{\mathrm{t}}$ & $\begin{array}{c}1.854^{* * *} \\
(0.548)\end{array}$ & $\begin{array}{c}0.802 \\
(0.693)\end{array}$ & $\begin{array}{c}-3.640^{* * *} \\
(0.877)\end{array}$ & $\begin{array}{c}-0.0607 \\
(0.765)\end{array}$ & $\begin{array}{l}-1.132 \\
(0.913)\end{array}$ & $\begin{array}{l}0.0645 \\
(0.113)\end{array}$ & $\begin{array}{c}1.147 \\
(1.497)\end{array}$ \\
\hline AD_IND_INT $t$ & $\begin{array}{c}69,215 \\
(43,201)\end{array}$ & $\begin{array}{c}46,972 \\
(60,335)\end{array}$ & $\begin{array}{l}-78,904 \\
(61,785)\end{array}$ & $\begin{array}{c}23,605 \\
(60,260)\end{array}$ & $\begin{array}{c}12,446 \\
(71,941)\end{array}$ & $\begin{array}{l}-4882 \\
(8934)\end{array}$ & $\begin{array}{c}2356 \\
(117,935)\end{array}$ \\
\hline LN_FIRM_AGE $t$ & $\begin{array}{l}0.0504 \\
(0.200)\end{array}$ & $\begin{array}{c}0.179 \\
(0.294)\end{array}$ & $\begin{array}{c}-0.0201 \\
(0.276)\end{array}$ & $\begin{array}{c}-0.532 * \\
(0.279)\end{array}$ & $\begin{array}{c}0.132 \\
(0.333)\end{array}$ & $\begin{array}{c}0.0506 \\
(0.0413)\end{array}$ & $\begin{array}{l}-0.611 \\
(0.545)\end{array}$ \\
\hline Industry dummy & Included & Included & Included & Included & Included & Included & Included \\
\hline Observations & 1060 & 504 & 556 & 1060 & 1060 & 1060 & 1060 \\
\hline R-squared & 0.071 & 0.071 & 0.090 & 0.110 & 0.176 & 0.497 & 0.200 \\
\hline
\end{tabular}

Note: Standard errors in parentheses. ${ }^{* * *},{ }^{* *},{ }^{*}$ represent significance at the $0.01,0.05$ and 0.1 level, respectively.

Such mixed evidence appears to have a close association with the characteristics of the materials industries in the Korean market. The materials industry explains more than $80 \%$ of the sample of environmentally sensitive industries, as indicated in Table 1. Choi and Lee [41] argue that firms in the materials industry participate substantially in earnings management with the use of discretionary accruals. In contrast, Ahn and Kim [14] argue that firms in the materials industry do not actively manage earnings with real activity management. Accordingly, socially responsible firms in the materials industry may be less likely to use abnormal discretionary accruals but may not exhibit significantly a different use of real activity manipulation compared to ordinary firms.

Table 6 confirms the above argument with regard to the materials industry. The table only considers the sample of firm-year observations belonging to the materials industry in estimating the relationship between CSR activity and financial reporting quality. The proxy variables for the use of discretionary accruals and real activity manipulation are separately analyzed as well. The set of control variables are identical to those of Table 4; Table 5. 
Table 6. CSR and Financial Reporting Quality: Materials Industry.

\begin{tabular}{|c|c|c|c|c|c|c|c|}
\hline Variable & ABS_DA & POSITIVE_DA & NEGATIVE_DA & AB_CFO & AB_PROD & AB_EXP & COMB_RAM \\
\hline $\mathrm{ESG} \mathrm{SCORE}_{\mathrm{t}}$ & $\begin{array}{c}-0.636^{* * *} \\
(0.200)\end{array}$ & $\begin{array}{c}-0.763 * * * \\
(0.264)\end{array}$ & $\begin{array}{l}0.499 * \\
(0.295)\end{array}$ & $\begin{array}{l}-0.220 \\
(0.274)\end{array}$ & $\begin{array}{c}0.516 \\
(0.329)\end{array}$ & $\begin{array}{l}-0.0183 \\
(0.0416)\end{array}$ & $\begin{array}{l}-0.806 \\
(0.542)\end{array}$ \\
\hline $\operatorname{SIZE}_{\mathrm{t}-1}$ & $\begin{array}{c}-0.177^{* *} \\
(0.0752)\end{array}$ & $\begin{array}{c}-0.138 \\
(0.0998)\end{array}$ & $\begin{array}{l}0.194 * \\
(0.111)\end{array}$ & $\begin{array}{c}0.218^{* *} \\
(0.103)\end{array}$ & $\begin{array}{c}-0.242 * \\
(0.124)\end{array}$ & $\begin{array}{c}0.0151 \\
(0.0156)\end{array}$ & $\begin{array}{c}0.499^{* *} \\
(0.204)\end{array}$ \\
\hline $\mathrm{MB}_{\mathrm{t}-1}$ & $\begin{array}{c}1.319^{* * *} \\
(0.244)\end{array}$ & $\begin{array}{c}1.978^{* * *} \\
(0.352)\end{array}$ & $\begin{array}{c}-0.779 * * \\
(0.338)\end{array}$ & $\begin{array}{c}0.839^{* *} \\
(0.334)\end{array}$ & $\begin{array}{c}-1.683^{* * *} \\
(0.401)\end{array}$ & $\begin{array}{c}0.0381 \\
(0.0507)\end{array}$ & $\begin{array}{c}2.726^{* * *} \\
(0.660)\end{array}$ \\
\hline ADJ_ROA t-1 & $\begin{array}{l}-3.176 \\
(2.634)\end{array}$ & $\begin{array}{l}-5.878 \\
(3.662)\end{array}$ & $\begin{array}{c}0.577 \\
(3.808)\end{array}$ & $\begin{array}{c}17.96^{* * *} \\
(3.610)\end{array}$ & $\begin{array}{c}-26.67^{* * *} \\
(4.336)\end{array}$ & $\begin{array}{c}0.541 \\
(0.548)\end{array}$ & $\begin{array}{c}45.96^{* * *} \\
(7.132)\end{array}$ \\
\hline LEV $_{t-1}$ & $\begin{array}{l}2.136^{* *} \\
(0.917)\end{array}$ & $\begin{array}{c}1.007 \\
(1.229)\end{array}$ & $\begin{array}{l}-2.582 * \\
(1.348)\end{array}$ & $\begin{array}{c}-4.394^{* * *} \\
(1.257)\end{array}$ & $\begin{array}{l}3.124^{* *} \\
(1.510)\end{array}$ & $\begin{array}{l}0.0630 \\
(0.191)\end{array}$ & $\begin{array}{c}-7.527^{* * *} \\
(2.483)\end{array}$ \\
\hline$E O_{t}$ & $\begin{array}{c}2.577^{* * *} \\
(0.628)\end{array}$ & $\begin{array}{c}1.465^{* *} \\
(0.726)\end{array}$ & $\begin{array}{c}-4.981^{* * *} \\
(1.104)\end{array}$ & $\begin{array}{l}-0.789 \\
(0.861)\end{array}$ & $\begin{array}{l}-0.992 \\
(1.035)\end{array}$ & $\begin{array}{l}0.233^{*} \\
(0.131)\end{array}$ & $\begin{array}{c}0.423 \\
(1.701)\end{array}$ \\
\hline RD_INT $_{t}$ & $\begin{array}{l}-3.947 \\
(18.77)\end{array}$ & $\begin{array}{c}9.051 \\
(25.35)\end{array}$ & $\begin{array}{c}17.95 \\
(27.18)\end{array}$ & $\begin{array}{c}34.90 \\
(25.72)\end{array}$ & $\begin{array}{c}-187.5^{* * *} \\
(30.90)\end{array}$ & $\begin{array}{c}87.60^{* * *} \\
(3.906)\end{array}$ & $\begin{array}{c}307.7^{* * *} \\
(50.82)\end{array}$ \\
\hline AD_IND_INT ${ }_{t}$ & $\begin{array}{c}16,483 \\
(83,068)\end{array}$ & $\begin{array}{c}83,992 \\
(111,952)\end{array}$ & $\begin{array}{c}36,393 \\
(121,036)\end{array}$ & $\begin{array}{c}58,646 \\
(113,876)\end{array}$ & $\begin{array}{c}103,202 \\
(136,782)\end{array}$ & $\begin{array}{l}-12,062 \\
(17,291)\end{array}$ & $\begin{array}{c}-78,005 \\
(224,961)\end{array}$ \\
\hline LN_FIRM_AGE & $\begin{array}{c}0.239 \\
(0.228)\end{array}$ & $\begin{array}{c}0.421 \\
(0.328)\end{array}$ & $\begin{array}{l}-0.194 \\
(0.321)\end{array}$ & $\begin{array}{c}-0.918^{* * *} \\
(0.313)\end{array}$ & $\begin{array}{l}0.0906 \\
(0.376)\end{array}$ & $\begin{array}{c}0.0575 \\
(0.0476)\end{array}$ & $\begin{array}{l}-0.946 \\
(0.619)\end{array}$ \\
\hline Observations & 885 & 425 & 460 & 885 & 885 & 885 & 885 \\
\hline R-squared & 0.104 & 0.144 & 0.101 & 0.110 & 0.147 & 0.386 & 0.170 \\
\hline
\end{tabular}

Note: Standard errors in parentheses. ${ }^{* *},{ }^{* *},{ }^{*}$ represent significance at the $0.01,0.05$ and 0.1 level, respectively.

Table 6 clearly indicates that more socially responsible firms in materials industries are less likely to participate in earnings management with the use of discretionary accrual. The coefficients on ESG scores are significantly negative for both cases of the absolute and positive values of discretionary accruals and the coefficient is significantly positive for the case of negative values of discretionary accruals. All three coefficients support a limited use of discretionary accruals for socially responsible firms in the industry. However, as argued above, none of the coefficients on the ESG score have any statistically significant relationship with the proxy variables for real activity management. Such characteristics of the materials industry appear to affect the estimation results in the environmentally sensitive industries, and eventually the estimation results in the entire sample of Korean firms.

The results of Table 6 are in line with the substitution hypothesis in the literature of earnings management $[16,17]$. The hypothesis expects that a CEO chooses the method of earnings management depending on a firm's economic environment. Accordingly, more socially responsible firms within the material industry may provide more transparent financial reporting in terms of discretionary accruals because the use of discretionary accruals is the major earnings management tool within the industry. The stakeholders within the material industry may not care significantly about earnings managements via real activity manipulations, which provides a low incentive for socially responsible firms to provide a higher quality of reporting in terms of real activity manipulations.

In Table 7, we examine the relationship between CSR activities and the quality of financial reporting for the group of firms in environmentally non-sensitive industries. In line with the previous tables, we analyze the proxy variables for the use of discretionary accruals and real activity manipulation separately. We also include the benchmark set of control variables as well.

Table 7 generally confirms a higher quality of financial reporting for more socially responsible firms in environmentally non-sensitive industries. All of the empirical models, except the case with negative abnormal discretionary accruals, show expected signs on the ESG score, in line with our first empirical hypothesis. The coefficients on ESG scores for these six models are all statistically significant, which argue for a higher quality of financial reporting in terms of both discretionary accrual and real activity management. This finding is exactly consistent with the U.S. evidence of Kim et al. [1] showing a better quality of financial reporting for more socially responsible firms in the U.S. markets. 
Table 7. CSR and Financial Reporting Quality: Environmentally Non-Sensitive Industries.

\begin{tabular}{|c|c|c|c|c|c|c|c|}
\hline Variable & ABS_DA & POSITIVE_DA & NEGATIVE_DA & AB_CFO & AB_PROD & AB_EXP & COMB_RAM \\
\hline ESG SCORE $_{t}$ & $\begin{array}{c}-0.193^{* *} \\
(0.0949)\end{array}$ & $\begin{array}{c}-0.417^{* * *} \\
(0.135)\end{array}$ & $\begin{array}{c}-0.0122 \\
(0.133)\end{array}$ & $\begin{array}{c}0.293^{* *} \\
(0.123)\end{array}$ & $\begin{array}{c}-0.543 * * \\
(0.238)\end{array}$ & $\begin{array}{l}0.150^{* * *} \\
(0.0408)\end{array}$ & $\begin{array}{c}0.983 * * * \\
(0.323)\end{array}$ \\
\hline SIZE $_{t-1}$ & $\begin{array}{c}-0.206^{* * *} \\
(0.0401)\end{array}$ & $\begin{array}{c}-0.110 * * \\
(0.0552)\end{array}$ & $\begin{array}{l}0.310^{* * *} \\
(0.0582)\end{array}$ & $\begin{array}{c}-0.134^{* *} \\
(0.0519)\end{array}$ & $\begin{array}{l}0.175^{*} \\
(0.101)\end{array}$ & $\begin{array}{l}0.00511 \\
(0.0173)\end{array}$ & $\begin{array}{c}-0.297^{* *} \\
(0.137)\end{array}$ \\
\hline $\mathrm{MB}_{\mathrm{t}-1}$ & $\begin{array}{c}0.610^{* * *} \\
(0.0940)\end{array}$ & $\begin{array}{c}0.683^{* * *} \\
(0.133)\end{array}$ & $\begin{array}{c}-0.532 * * * \\
(0.132)\end{array}$ & $\begin{array}{c}0.770 * * * \\
(0.122)\end{array}$ & $\begin{array}{c}-1.790^{* * *} \\
(0.236)\end{array}$ & $\begin{array}{l}0.385^{* * *} \\
(0.0404)\end{array}$ & $\begin{array}{c}2.761^{* * *} \\
(0.320)\end{array}$ \\
\hline ADJ_ROA $t-1$ & $\begin{array}{c}-7.816^{* * *} \\
(1.434)\end{array}$ & $\begin{array}{c}-6.647^{* * *} \\
(2.032)\end{array}$ & $\begin{array}{c}8.995^{* * *} \\
(2.023)\end{array}$ & $\begin{array}{c}13.80^{* * *} \\
(1.856)\end{array}$ & $\begin{array}{c}-20.03^{* * *} \\
(3.604)\end{array}$ & $\begin{array}{c}-0.0120 \\
(0.617)\end{array}$ & $\begin{array}{c}33.57^{* * *} \\
(4.886)\end{array}$ \\
\hline $\operatorname{LEV}_{t-1}$ & $\begin{array}{c}2.130^{* * *} \\
(0.531)\end{array}$ & $\begin{array}{l}1.223 * \\
(0.728) \\
\end{array}$ & $\begin{array}{c}-2.950 * * * \\
(0.778) \\
\end{array}$ & $\begin{array}{c}-4.272 * * * \\
(0.687)\end{array}$ & $\begin{array}{c}8.772 * * * \\
(1.334) \\
\end{array}$ & $\begin{array}{c}-1.566^{* * *} \\
(0.228) \\
\end{array}$ & $\begin{array}{c}-15.15^{* * *} \\
(1.809) \\
\end{array}$ \\
\hline $\mathrm{EO}_{\mathrm{t}}$ & $\begin{array}{c}1.067^{* * *} \\
(0.361) \\
\end{array}$ & $\begin{array}{c}1.491^{* * *} \\
(0.484)\end{array}$ & $\begin{array}{l}-0.565 \\
(0.536) \\
\end{array}$ & $\begin{array}{c}-1.541^{* * *} \\
(0.467)\end{array}$ & $\begin{array}{c}2.170 * * \\
(0.907) \\
\end{array}$ & $\begin{array}{l}-0.163 \\
(0.155) \\
\end{array}$ & $\begin{array}{c}-3.900 * * * \\
(1.230) \\
\end{array}$ \\
\hline RD_INT $_{\mathrm{t}}$ & $\begin{array}{l}-7.900 \\
(6.405)\end{array}$ & $\begin{array}{l}-8.610 \\
(9.435)\end{array}$ & $\begin{array}{c}8.732 \\
(8.831)\end{array}$ & $\begin{array}{c}1.555 \\
(8.287)\end{array}$ & $\begin{array}{c}-41.24^{* *} \\
(16.09)\end{array}$ & $\begin{array}{c}67.44^{* * *} \\
(2.754)\end{array}$ & $\begin{array}{c}111.9^{* * *} \\
(21.82)\end{array}$ \\
\hline AD_IND_INT & $\begin{array}{l}2024 * \\
(1118)\end{array}$ & $\begin{array}{c}1116 \\
(1529)\end{array}$ & $\begin{array}{l}-2752 * \\
(1629)\end{array}$ & $\begin{array}{l}-642.7 \\
(1447)\end{array}$ & $\begin{array}{l}132.8 \\
(2809)\end{array}$ & $\begin{array}{c}-1719^{* * *} \\
(480.7)\end{array}$ & $\begin{array}{l}-3282 \\
(3809)\end{array}$ \\
\hline LN_FIRM_AGE $t$ & $\begin{array}{l}-0.125 \\
(0.143)\end{array}$ & $\begin{array}{l}-0.178 \\
(0.194)\end{array}$ & $\begin{array}{l}0.0888 \\
(0.209)\end{array}$ & $\begin{array}{c}0.171 \\
(0.184)\end{array}$ & $\begin{array}{c}1.486^{* * *} \\
(0.358)\end{array}$ & $\begin{array}{c}-0.172 * * * \\
(0.0613)\end{array}$ & $\begin{array}{c}-1.640^{* * *} \\
(0.485)\end{array}$ \\
\hline Industry dummy & Included & Included & Included & Included & Included & Included & Included \\
\hline Observations & 2713 & 1311 & 1402 & 2713 & 2713 & 2713 & 2713 \\
\hline R-squared & 0.091 & 0.085 & 0.105 & 0.085 & 0.092 & 0.264 & 0.132 \\
\hline
\end{tabular}

Note: Standard errors in parentheses. ${ }^{* * *},{ }^{* *},{ }^{*}$ represent significance at the $0.01,0.05$ and 0.1 level, respectively.

We next turn to examine the role of chaebol affiliates in the relationship between CSR activity and the quality of financial reporting. In line with Table 5; Table 7, we split the entire sample of firm-year observations into the categories of chaebol affiliates and non-chaebol affiliates. Yoon and Lee [39] argue that the different economic conditions between chaebol affiliates and non-chaebol affiliates may influence the effects of CSR activities on corporate policies. Yoon et al. [12] also provide similar conclusions. Table 8 restricts the sample of firm-year observations belonging to chaebol affiliates and Table 9 considers the firm-year observations within non-chaebol affiliates. For each table, we initially investigate the proxy variables related to the use of discretionary accruals and next examine the proxy variables for real production management variables. Both tables use the same set of control variables as in Table 4 and include the industry fixed effect terms.

Table 8 provides empirical evidence supporting our second hypothesis, H2. For all of the empirical models except abnormal expenses, the estimated coefficients are statistically insignificant. Even for the case of abnormal expenses, the coefficient is only marginally positive at a statistical significance level of $10 \%$. Unlike all of the previous examinations, we find no strong evidence that the sample of chaebol affiliates is less likely to use discretionary accruals to manage earnings.

This finding is closely associated with the special economic environments of chaebol affiliates. Chaebol affiliates are subject to continuous monitoring by the Korean Supervisory Service and the Korea Fair Trade Commission [39]. The chaebol affiliates have to meet with stricter requirements related to their disclosure, financing, and governance structures. For instance, the chaebol affiliates have responsibility to report their board structure, controlling shareholders, and large business transactions periodically. A significant amount of intra-group trading has to be publicly reported across firms in a specific chaebol group. Even non-publicly traded chaebol affiliates have their financial statements audited by a registered CPA. In fact, firms belonging to chaebol affiliates have limitations in debt issuance and cross-debt guarantees, which lower asymmetric information between the firms and shareholders. For instance, Park et al. [13] argue that chaebol affiliates manage their firms in a more transparent way based on measures built on the transparency of operation, governance structure, and financial reporting quality, especially after the East Asian crisis of 1997. 
Table 8. CSR and Financial Reporting Quality: Chaebol Affiliates.

\begin{tabular}{|c|c|c|c|c|c|c|c|}
\hline Variable & ABS_DA & POSITIVE_DA & NEGATIVE_DA & AB_CFO & AB_PROD & AB_EXP & COMB_RAM \\
\hline $\mathrm{ESG} \mathrm{SCORE}_{\mathrm{t}}$ & $\begin{array}{l}-0.110 \\
(0.134)\end{array}$ & $\begin{array}{l}-0.229 \\
(0.198)\end{array}$ & $\begin{array}{c}-0.0312 \\
(0.184)\end{array}$ & $\begin{array}{c}-0.000480 \\
(0.180)\end{array}$ & $\begin{array}{l}-0.210 \\
(0.318)\end{array}$ & $\begin{array}{l}0.0951 * \\
(0.0500)\end{array}$ & $\begin{array}{c}0.341 \\
(0.458)\end{array}$ \\
\hline $\mathrm{MB}_{\mathrm{t}-1}$ & $\begin{array}{c}0.603 * * * \\
(0.165)\end{array}$ & $\begin{array}{c}1.036^{* * *} \\
(0.237)\end{array}$ & $\begin{array}{l}-0.142 \\
(0.235)\end{array}$ & $\begin{array}{l}0.452 \text { ** } \\
(0.220)\end{array}$ & $\begin{array}{c}-0.752^{*} \\
(0.390)\end{array}$ & $\begin{array}{l}0.196^{* * *} \\
(0.0613)\end{array}$ & $\begin{array}{l}0.962 * \\
(0.562)\end{array}$ \\
\hline $\operatorname{LEV}_{t-1}$ & $\begin{array}{c}2.263 * * \\
(1.029)\end{array}$ & $\begin{array}{c}-0.0357 \\
(1.507)\end{array}$ & $\begin{array}{c}-3.670 * * \\
(1.430)\end{array}$ & $\begin{array}{c}-2.944^{* *} \\
(1.377)\end{array}$ & $\begin{array}{c}6.364^{* * *} \\
(2.436)\end{array}$ & $\begin{array}{c}-0.883 * * \\
(0.383)\end{array}$ & $\begin{array}{c}-10.57^{* * *} \\
(3.512)\end{array}$ \\
\hline $\mathrm{EO}_{\mathrm{t}}$ & $\begin{array}{l}1.088 * \\
(0.595)\end{array}$ & $\begin{array}{c}1.070 \\
(0.852)\end{array}$ & $\begin{array}{c}-1.526 * \\
(0.848)\end{array}$ & $\begin{array}{c}-1.533 * \\
(0.796)\end{array}$ & $\begin{array}{c}0.277 \\
(1.408)\end{array}$ & $\begin{array}{c}0.216 \\
(0.221)\end{array}$ & $\begin{array}{l}-1.483 \\
(2.030)\end{array}$ \\
\hline AD_IND_INT $\mathbf{t}$ & $\begin{array}{l}-2940 \\
(2522)\end{array}$ & $\begin{array}{c}-7082 * * \\
(3419)\end{array}$ & $\begin{array}{l}-1637 \\
(3942)\end{array}$ & $\begin{array}{l}-1771 \\
(3375)\end{array}$ & $\begin{array}{c}-13,694 \text { ** } \\
(5968)\end{array}$ & $\begin{array}{c}1097 \\
(938.6)\end{array}$ & $\begin{array}{l}11,897 \\
(8606)\end{array}$ \\
\hline LN_FIRM_AGE ${ }_{t}$ & $\begin{array}{l}0.0245 \\
(0.226)\end{array}$ & $\begin{array}{l}-0.155 \\
(0.336)\end{array}$ & $\begin{array}{l}-0.178 \\
(0.309)\end{array}$ & $\begin{array}{c}0.158 \\
(0.303)\end{array}$ & $\begin{array}{c}1.950^{* * *} \\
(0.536)\end{array}$ & $\begin{array}{l}-0.144 * \\
(0.0843)\end{array}$ & $\begin{array}{c}-2.275^{* * *} \\
(0.773)\end{array}$ \\
\hline Industry dummy & Included & Included & Included & Included & Included & Included & Included \\
\hline Observations & 927 & 428 & 499 & 927 & 927 & 927 & 927 \\
\hline R-squared & 0.089 & 0.121 & 0.099 & 0.075 & 0.129 & 0.298 & 0.145 \\
\hline
\end{tabular}

Note: Standard errors in parentheses. ${ }^{* * *},{ }^{* *},{ }^{*}$ represent significance at the $0.01,0.05$ and 0.1 level, respectively.

As a result, more socially responsible firms within chaebol affiliates may already have high quality financial reporting because of strict and continuous monitoring by the Korean Supervisory Service and the Korea Fair Trade Commission. The stakeholders for these firms may have limited demand to additionally enhance the transparency of financial reporting. Thus, socially responsible firms within chaebol affiliates may not have significant incentives to enhance the quality of their financial reporting, even with the use of discretionary accruals. Of course, these firms may be less likely to use real activity manipulation as well.

Table 9 provides contrasting results from Table 8, which argues for both of our empirical hypotheses, $\mathrm{H} 1$ and $\mathrm{H} 2$. For all of the empirical models, except the case of negative discretionary accruals, the table presents supporting evidence for a better quality of financial reporting by more socially responsible firms. The coefficients on the ESG scores for these six models are all statistically significant, which argues for our first empirical hypothesis, H1. Such a higher quality of financial reporting by non-chaebol affiliates also suggests the importance of chaebol affiliates' characteristics in deciding the effect of CSR performance on financial reporting, which is also in line with our second empirical hypothesis.

Table 9. CSR and Financial Reporting Quality: Non-Chaebol Affiliates.

\begin{tabular}{cccccccc}
\hline Variable & ABS_DA & POSITIVE_DA & NEGATIVE_DA & AB_CFO & AB_PROD & AB_EXP & COMB_RAM \\
\hline \multirow{2}{*}{ ESG SCORE } & $-0.292^{* * *}$ & $-0.619^{* * *}$ & -0.00503 & $0.251^{*}$ & $-0.497^{*}$ & $0.130^{* * *}$ & $0.868^{* *}$ \\
& $(0.112)$ & $(0.155)$ & $(0.161)$ & $(0.146)$ & $(0.260)$ & $(0.0442)$ & $(0.357)$ \\
\hline \multirow{2}{*}{ SIZE $_{\mathbf{t}-\mathbf{1}}$} & $-0.211^{* * *}$ & $-0.127^{* *}$ & $0.298^{* * *}$ & -0.0376 & 0.0185 & 0.00620 & -0.0384 \\
& $(0.0413)$ & $(0.0552)$ & $(0.0613)$ & $(0.0538)$ & $(0.0962)$ & $(0.0163)$ & $(0.132)$ \\
\hline \multirow{2}{*}{ MB $_{\mathbf{t}-\mathbf{1}}$} & $0.601^{* * *}$ & $0.599^{* * *}$ & $-0.560^{* * *}$ & $0.933^{* * *}$ & $-2.299^{* * *}$ & $0.373^{* * *}$ & $3.560^{* * *}$ \\
& $(0.100)$ & $(0.144)$ & $(0.139)$ & $(0.131)$ & $(0.233)$ & $(0.0396)$ & $(0.320)$ \\
\hline \multirow{2}{*}{ ADJ_ROA $\mathbf{t - 1}$} & $-5.352^{* * *}$ & $-4.506^{* *}$ & $6.079^{* * *}$ & $14.89^{* * *}$ & $-19.95^{* * *}$ & -0.131 & $34.52^{* * *}$ \\
& $(1.334)$ & $(1.824)$ & $(1.943)$ & $(1.738)$ & $(3.105)$ & $(0.528)$ & $(4.265)$ \\
\hline \multirow{2}{*}{ LEV $_{\mathbf{t}-\mathbf{1}}$} & $2.511^{* * *}$ & $1.883^{* * *}$ & $-2.934^{* * *}$ & $-4.619^{* * *}$ & $6.981^{* * *}$ & $-1.1122^{* * *}$ & $-13.08^{* * *}$ \\
& $(0.512)$ & $(0.685)$ & $(0.760)$ & $(0.667)$ & $(1.191)$ & $(0.202)$ & $(1.635)$ \\
\hline
\end{tabular}


Table 9. Cont.

\begin{tabular}{|c|c|c|c|c|c|c|c|}
\hline Variable & ABS_DA & POSITIVE_DA & NEGATIVE_DA & AB_CFO & AB_PROD & AB_EXP & COMB_RAM \\
\hline$E O_{t}$ & $\begin{array}{c}1.389 * * * \\
(0.360)\end{array}$ & $\begin{array}{c}1.469 \text { *** } \\
(0.460)\end{array}$ & $\begin{array}{c}-1.340 * * \\
(0.560)\end{array}$ & $\begin{array}{c}-1.127^{* *} \\
(0.469)\end{array}$ & $\begin{array}{l}1.549 * \\
(0.837)\end{array}$ & $\begin{array}{l}-0.171 \\
(0.142)\end{array}$ & $\begin{array}{c}-2.929 * * \\
(1.150)\end{array}$ \\
\hline $\mathrm{RD}_{-} \mathrm{INT}_{\mathrm{t}}$ & $\begin{array}{c}1.303 \\
(6.899)\end{array}$ & $\begin{array}{l}-1.548 \\
(9.883)\end{array}$ & $\begin{array}{l}-2.444 \\
(9.690)\end{array}$ & $\begin{array}{l}-4.338 \\
(8.989)\end{array}$ & $\begin{array}{c}-38.98 * * \\
(16.06)\end{array}$ & $\begin{array}{c}70.50 * * * \\
(2.730)\end{array}$ & $\begin{array}{c}107.2^{* * *} \\
(22.05)\end{array}$ \\
\hline AD_IND_INT $\mathbf{t}$ & $\begin{array}{c}3517 * * * \\
(1268)\end{array}$ & $\begin{array}{c}3478 * * \\
(1706)\end{array}$ & $\begin{array}{c}-3690 * * \\
(1872)\end{array}$ & $\begin{array}{l}-1534 \\
(1653)\end{array}$ & $\begin{array}{c}3728 \\
(2952)\end{array}$ & $\begin{array}{c}-1969 * * * \\
(501.8)\end{array}$ & $\begin{array}{c}-7904 * \\
(4055)\end{array}$ \\
\hline LN_FIRM_AGE $t$ & $\begin{array}{c}-0.0600 \\
(0.141)\end{array}$ & $\begin{array}{c}-0.0189 \\
(0.191)\end{array}$ & $\begin{array}{l}0.0723 \\
(0.206)\end{array}$ & $\begin{array}{l}-0.198 \\
(0.183)\end{array}$ & $\begin{array}{c}0.990^{* * *} \\
(0.328)\end{array}$ & $\begin{array}{l}-0.0863 \\
(0.0557)\end{array}$ & $\begin{array}{c}-1.301^{* * *} \\
(0.450)\end{array}$ \\
\hline Industry dummy & Included & Included & Included & Included & Included & Included & Included \\
\hline Observations & 2744 & 1338 & 1406 & 2744 & 2744 & 2744 & 2744 \\
\hline R-squared & 0.088 & 0.088 & 0.096 & 0.102 & 0.103 & 0.263 & 0.151 \\
\hline
\end{tabular}

Note: Standard errors in parentheses. ${ }^{* * *},{ }^{* *},{ }^{*}$ represent significance at the $0.01,0.05$ and 0.1 level, respectively.

\subsection{Discussion}

Table 4 weakly supports the first hypothesis implying a better quality of financial reporting by more socially responsible firms in the Korean financial market. The table shows that socially responsible firms are less likely to manage earnings by using the discretionary accruals. The table also shows that more socially responsible firms limit their earnings management based on expense management and these firms at least do not more actively participate in real activity management. This result generally suggests that more socially responsible firms may provide a better quality of financial reporting even in a developing country.

Tables 5-7 imply that such weak results in the Korean market are mainly driven by the sample belonging to the materials industry, which is known to use discretionary accrual more significantly and real activity manipulation less significantly in their choice of earnings management tools. More socially responsible firms in the materials industry, which are categorized as environmentally sensitive ones, are significantly less likely to use discretionary accruals without exhibiting a significant difference in their use of real activity management. In contrast, socially responsible firms in environmentally non-sensitive industries are less likely to participate in earnings management via both measures of discretionary accruals and real activity manipulations.

Table 8; Table 9 provide more interesting results. Socially responsible firms in chaebol affiliates are not less likely to have a better quality of financial reporting in terms of both measures of the earnings management. However, non-chaebol affiliates are less likely to manage earnings with the use of discretionary accruals and real activity management. These contrasting results appear to be closely associated with the distinctive corporate environment of chaebol affiliates. The firms belonging to chaebol affiliates are under quite strict supervision by the Korean Supervision Service, which already requires a high quality of financial reporting, stricter auditing, significant limitations in financing methods, and so on. Accordingly, socially responsible firms in chaebol affiliates may already have high quality financial reporting, which reduces incentives to improve the quality of their financial information.

These findings support recent studies highlighting the role of firm characteristics in deciding the effect of socially responsibility on corporate policies. For instance, Miralles-Quirós et al. [11] emphasize the role of environmentally sensitive industries in shaping the effect of CSR on corporate decisions in the Brazilian market. Similar to our work, Yoon et al. [12] highlight the significant role of chaebol and non-chaebol categorization in the valuation effect of ESG scores. Our results imply that more socially responsible firms weakly have a better quality of financial reporting in the overall Korean financial market itself. By inspecting firm characteristics closely, we show that this weak set of evidence is mainly driven by firms that belong to materials industries and chaebol affiliates. In fact, we find strong evidence for a better quality of financial reporting by environmentally non-sensitive industries and non-chaebol affiliates. 


\section{Conclusions}

This paper investigates how a firm's CSR activity affects its quality of financial reporting in the Korean financial market from the perspective of earnings management. To measure the degree of earnings management, we adopt various proxy variables related to the use of discretionary accruals and real activities manipulations. A firm's level of CSR activity is also measured by the sum of the environmental, social, and corporate governance (ESG) score published by the Korea Corporate Governance Service (KCGS). We adopt cross-sectional regression models to test the hypothesis with a sample of publicly traded Korean firms from 2010 to 2015. Building upon recent studies [11,12] and highlighting the role of firm characteristics in shaping the effect of CSR activity on corporate policies, a sub-sample analysis is conducted for the group of environmentally sensitive industries and non-sensitive industries and for the group of chaebol affiliates and non-chaebol affiliates.

This paper provides an interesting set of results. Most of all, our analysis of the entire sample of Korean firms weakly supports a better quality of financial reporting by more socially responsible firms. Socially responsible firms are less likely to manage earnings by using discretionary accruals, but they do not exhibit strongly different patterns in the use of real activity manipulation. However, our subsample analysis confirms that such kind of weak results are mainly driven by the firms belonging to environmentally sensitive industries, particularly materials industry or bye the firms belonging to chaebol affiliates. More socially responsible firms in environmentally non-sensitive industries and nonchaebol affiliates are less likely to participate in earnings management in terms of both discretionary accruals and real activity manipulations.

Our results indicate that a firm's characteristics and operation environment affect the relationship between CSR activities and the quality of financial reporting. For instance, chaebol affiliates are subject to continuous and strict monitoring by the Korean Supervisory Service with regard to their financing policies, cross-trading, and auditing. Chaebol affiliates already have a higher quality of financial reporting information due to such strict supervision and thus more socially responsible firms in the group may not have a strong incentive to additionally raise the quality of financial reporting. Furthermore, the materials industry, which comprises more than $80 \%$ of the samples in environmentally sensitive industries in Korea, is known to favor discretionary accruals rather than real activity manipulation as a key method for earnings management in the market [14,41]. Accordingly, more socially responsible firms in the materials industry are less likely to use discretionary accruals but show no difference in the use of real activity manipulations.

This paper adds new insights to the extant literature in a number of respects. Most of all, our analysis suggests the possibility of a higher quality of financial reporting for more socially responsible firms even within emerging markets. The extant literature mainly focuses on advanced markets [1,9] or examines a limited sample of observations across countries [3,15]. More importantly, our analysis emphasizes that firm characteristics play an important role in shaping the relationship between CSR performance and the quality of reported earnings. This result is in contrast to the extant studies generally highlighting the unequivocal influence of CSR practices on the quality of financial reporting $[1,15]$. Finally, our results in the material industry are in line with the substitution hypothesis of earnings management in choice between discretionary accruals and real activity manipulation. More socially firms in the material industry only reduce the use of discretionary accruals, which is mainly used as earnings management tool in the industry.

We conclude by highlighting the limitations of our work. In terms of the estimation methodology, our study still does not overcome the problem of reverse causality, as Hart and Ahuja [42] note. Cross-sectional regression models do not fully control other potential biases, such as omitted variable biases. Furthermore, we did not conduct a detailed industry analysis, while our results on the materials industry implies significant inter-industry differences for the effects of CSR activities on the quality of financial reporting. These issues need to be addressed in future studies. 
Author Contributions: B.Y. collected data and contributed to organizing our work. B.K. implemented empirical models. J.H.L. initiated and directed the overall processes of our research, and wrote the paper.

Funding: This research received no specific grant from any funding agency in the public, commercial, or not-for-profit sectors.

Acknowledgments: In this section you can acknowledge any support given which is not covered by the author contribution or funding sections. This may include administrative and technical support, or donations in kind (e.g., materials used for experiments).

Conflicts of Interest: The authors declare no conflict of interest.

\section{References}

1. Kim, Y.; Park, M.S.; Wier, B. Is earnings quality associated with corporate social responsibility? Account. Rev. 2012, 87, 761-796. [CrossRef]

2. Kim, I.; Venkatachalam, M. Are sin stocks paying the price for accounting sins? J. Account. Audit. Financ. 2011, 26, 415-442. [CrossRef]

3. Chih, H.-L.; Shen, C.-H.; Kang, F.-C. Corporate social responsibility, investor protection, and earnings management: Some international evidence. J. Bus. Ethics 2008, 79, 179-198. [CrossRef]

4. Malik, M. Value-enhancing capabilities of CSR: A brief review of contemporary literature. J. Bus. Ethics 2015, 127, 419-438. [CrossRef]

5. Brammer, S.; Millington, A. Corporate reputation and philanthropy: An empirical analysis. J. Bus. Ethics 2005, 61, 29-44. [CrossRef]

6. Barth, M.E.; Landsman, W.R.; Lang, M.H. International accounting standards and accounting quality. J. Account. Res. 2008, 46, 467-498. [CrossRef]

7. Schipper, K.; Vincent, L. Earnings quality. Account. Horiz. 2003, 17, 97-110. [CrossRef]

8. Cohen, J.R.; Krishnamoorthy, G.; Wright, A. The corporate governance mosaic and financial reporting quality. J. Account. Lit. 2004, 23, 87-152.

9. Almahrog, Y.; Ali Aribi, Z.; Arun, T. Earnings management and corporate social responsibility: UK evidence. J. Financ. Report. Account. 2018, 16, 311-332. [CrossRef]

10. Scholtens, B.; Kang, F.C. Corporate social responsibility and earnings management: Evidence from Asian economies. Corp. Soc. Responsib. Environ. Manag. 2013, 20, 95-112. [CrossRef]

11. Miralles-Quirós, M.; Miralles-Quirós, J.; Valente Gonçalves, L. The value relevance of environmental, social, and governance performance: The Brazilian case. Sustainability 2018, 10, 574. [CrossRef]

12. Yoon, B.; Lee, J.; Byun, R. Does ESG performance enhance firm value? Evidence from Korea. Sustainability 2018, 10, 3635. [CrossRef]

13. Park, H.-J.; Shin, H.-H.; Kang, D.-K.; Kwon, I.-S. Corporate transparency and its value. Korean Manag. Rev. 2006, 35, 31.

14. Ahn, I.J.; Kim, J.Y. A study on detecting earnings management with operational activities by cross-sectional analysis. Account. Inf. Rev. 2009, 27, 25.

15. Hong, Y.; Andersen, M.L. The relationship between corporate social responsibility and earnings management: An exploratory study. J. Bus. Ethics 2011, 104, 461-471. [CrossRef]

16. Zang, A.Y. Evidence on the trade-off between real activities manipulation and accrual-based earnings management. Account. Rev. 2011, 87, 675-703. [CrossRef]

17. Chan, L.H.; Chen, K.C.; Chen, T.Y.; Yu, Y. Substitution between real and accruals-based earnings management after voluntary adoption of compensation clawback provisions. Account. Rev. 2014, 90, 147-174. [CrossRef]

18. Aguinis, H.; Glavas, A. What we know and don't know about corporate social responsibility: A review and research agenda. J. Manag. 2012, 38, 932-968. [CrossRef]

19. Garriga, E.; Melé, D. Corporate social responsibility theories: Mapping the territory. J. Bus. Ethics 2004, 53, 51-71. [CrossRef]

20. Peloza, J. The challenge of measuring financial impacts from investments in corporate social performance. J. Manag. 2009, 35, 1518-1541. [CrossRef]

21. Wood, D.J. Measuring corporate social performance: A review. Int. J. Manag. Rev. 2010, 12, 50-84. [CrossRef]

22. Peloza, J.; Shang, J. How can corporate social responsibility activities create value for stakeholders? A systematic review. J. Acad. Mark. Sci. 2011, 39, 117-135. [CrossRef] 
23. Brammer, S.J.; Pavelin, S. Corporate reputation and social performance: The importance of fit. J. Manag. Stud. 2006, 43, 435-455. [CrossRef]

24. Arora, N.; Henderson, T. Embedded premium promotion: Why it works and how to make it more effective. Mark. Sci. 2007, 26, 514-531. [CrossRef]

25. Sen, S.; Bhattacharya, C.B. Does doing good always lead to doing better? Consumer reactions to corporate social responsibility. J. Mark. Res. 2001, 38, 225-243. [CrossRef]

26. Maignan, I.; Ferrell, O.C.; Hult, G.T.M. Corporate citizenship: Cultural antecedents and business benefits. J. Acad. Mark. Sci. 1999, 27, 455-469. [CrossRef]

27. Greening, D.W.; Turban, D.B. Corporate social performance as a competitive advantage in attracting a quality workforce. Bus. Soc. 2000, 39, 254-280. [CrossRef]

28. Sharma, S.; Vredenburg, H. Proactive corporate environmental strategy and the development of competitively valuable organizational capabilities. Strateg. Manag. J. 1998, 19, 729-753. [CrossRef]

29. Johnson, R.A.; Greening, D.W. The effects of corporate governance and institutional ownership types on corporate social performance. Acad. Manag. J. 1999, 42, 564-576.

30. McWilliams, A.; Siegel, D. Corporate social responsibility: A theory of the firm perspective. Acad. Manag. Rev. 2001, 26, 117-127. [CrossRef]

31. Hemingway, C.A.; Maclagan, P.W. Managers' personal values as drivers of corporate social responsibility. J. Bus. Ethics 2004, 50, 33-44. [CrossRef]

32. Prior, D.; Surroca Aguilar, J.; Tribo Gine, J.A. Earnings management and corporate social responsibility. RePEc 2006.

33. Choi, H.; Moon, D. The relationship between corporate social responsibilities and accounting transparency. Korean Account. Rev. 2013, 38, 135-171.

34. Chun, S.; Cho, E. Differentiation strategy, CSR, and real activities earnings management: Evidence from Korea. J. Appl. Bus. Res. 2017, 33, 669-692. [CrossRef]

35. Jordaan, L.A.; De Klerk, M.; de Villiers, C.J. Corporate social responsibility and earnings management of South African companies. S. Afr. J. Econ. Manag. Sci. 2018, 21, 1-13. [CrossRef]

36. Lin, C.-S.; Chang, R.-Y.; Dang, V. An integrated model to explain how corporate social responsibility affects corporate financial performance. Sustainability 2015, 7, 8292-8311. [CrossRef]

37. Gavana, G.; Gottardo, P.; Moisello, A. Earnings management and CSR disclosure. Family vs. Non-family firms. Sustainability 2017, 9, 2327. [CrossRef]

38. Oh, W.Y.; Chang, Y.K.; Martynov, A. The effect of ownership structure on corporate social responsibility: Empirical evidence from Korea. J. Bus. Ethics 2011, 104, 283-297. [CrossRef]

39. Yoon, B.; Lee, J.H. Corporate social responsibility and information asymmetry in the Korean market: Implications of chaebol affiliates. J. Asian Financ. Econ. Bus. 2019, 6, 21-31. [CrossRef]

40. Choi, B.B.; Lee, D.; Park, Y. Corporate social responsibility, corporate governance and earnings quality: Evidence from Korea. Corp. Gov.: Int. Rev. 2013, 21, 447-467. [CrossRef]

41. Choi, H.D.; Lee, J.H. Relevance of industrial earnings management and stock prices. J. Tax. Account. 2017, $18,28$.

42. Hart, S.L.; Ahuja, G. Does it pay to be green? An empirical examination of the relationship between emission reduction and firm performance. Bus. Strategy Environ. 1996, 5, 30-37. [CrossRef]

(C) 2019 by the authors. Licensee MDPI, Basel, Switzerland. This article is an open access article distributed under the terms and conditions of the Creative Commons Attribution (CC BY) license (http://creativecommons.org/licenses/by/4.0/). 